\title{
PRASYARAT POLIGAMI DALAM KITAB FIQIH ISLAM DAN KOMPILASI HUKUM ISLAM PERSPEKTIF MASHLAHAH MURSALAH
}

\author{
Anwar Hafidzi \\ Universitas Islam Negeri Antasari I Jalan Ahmad Yani, Km. 4.5 Banjarmasin, \\ Kalimantan Selatan \\ anwar.hafidzi@gmail.com
}

\begin{abstract}
Abstract: This paper discusses about the problematic of the polygamy rules between text and context of the suitability of polygamy requirements stipulated in the Compilation of Islamic Law and some positive Indonesian law with the requirements and permissibility of polygamy in the book of Islamic Jurisprudence of Wahbah Zuhaili. According to Wahbah Zuhaili, the polygamy requirements are only two namely justice for their wives or children and a husband must be able to provide for the maintenance. Meanwhile, according to the Compilation of Islamic Law, several clauses explain the requirements that must be fulfilled by the husband when he wants to do polygamy. They are to maintain the welfare of the soul, wealth (livelihood), and environment. Zuhaili's mashlahah approach is more directed to the practice of polygamy that must really achieve the goodness of the Islamic law clearly and confidently, not just lust. While the mashlahah approach in the Compilation of Islamic Law leads more to the adjustment of the ability of the soul, the provision of decent living, there is no tendency among the bride's family, and not creating mudharat in the household and social life. The issue of the requirements as mentioned in the Islamic jurisprudence and the Compilation of Islamic Law has similarity as to avoid as much harm as possible.
\end{abstract}

Keywords: Prerequisites, polygamy, Islamic jurisprudence, Compilation of Islamic Law, mashlahah

Abstrak: Tulisan ini membahas problematika aturan poligami antara teks dan konteks yaitu kesesuaian persyaratan poligami yang diatur dalam Kompilasi Hukum Islam serta beberapa hukum positif Indonesia dengan persyaratan dan dibolehkannya poligami dalam kitab Fiqih Islam karangan Wahbah Zuhaili. Menurut Wahbah Zuhaili, persyaratan poligami hanya ada dua yaitu keadilan bagi para istri atau anak-anak 
mereka, dan seorang suami harus mampu memberi nafkah untuk memelihara kemaslahatannya. Sedangkan menurut Kompilasi Hukum Islam ada beberapa pasal yang menjelaskan persyaratan yang harus dilakukan oleh suami ketika ingin berpoligami, yaitu demi menjaga kemaslahatan jiwa, harta (nafkah), dan lingkungan. Pendekatan mashlahah Zuhaili lebih mengarah pada praktik poligami yang harus benar-benar mencapai kebaikan dari syariat Islam secara jelas dan yakin, bukan sekedar nafsu belaka. Sementara pendekatan mashlahah dalam $\mathrm{KHI}$ lebih mengarah pada penyesuaian kemampuan jiwa, pemberian nafkah yang layak, tidak ada tendensi antar keluarga mempelai, dan tidak menjadikan mudharat dalam rumah tangga dan lingkungan sosial masyarakat sekitarnya. Prasyarat poligami dari perspektif mashlahah antara kitab Fiqih Islam dan $\mathrm{KHI}$ memiliki kesamaan dalam masalah pemenuhan syarat berpoligami dan menghindari kemudharatan semaksimal mungkin.

Kata Kunci: Prasyarat, poligami, Fiqih Islam, KHI, mashlahah.

\section{Pendahuluan}

Poligami merupakan suatu sistem ikatan perkawinan yang dilakukan seorang laki-laki (suami) lebih dari satu istri pada waktu bersamaan. ${ }^{1}$ Memang tidak ada yang mengharamkan praktik poligami ini secara tekstual, al-Qur'an, hadits, bahkan di Negara Indonesia pun memperbolehkannya, meski yang menjadi pertanyaan besarnya adalah legalitas praktik poligami tersebut. ${ }^{2}$ Kajian berpoligami secara agama diantaranya termaktub dalam kitab Figh Islam Wa Adillatuh karya Wahbah Zuhaili yang memberikan prasyarat singkat dalam berpoligami. Sementara dalam Kompilasi Hukum Islam (KHI) memberikan beberapa syarat yang harus dilengkapi jika ingin mendapatkan legalitas dalam Undang-undang Republik Indonesia. ${ }^{3}$ Maka diperlukan

\footnotetext{
I Mohammad Nurrizal Fanani, "Pemberian Izin Poligami Oleh Pengadilan Agama Kudus Ditinjau dari Perspektif Hukum Islam" (Universitas Muria Kudus, 20 I7), http://eprints.umk.ac.id/7263/

2 Tujuan utama pernikahan adalah bersifat ikatan lahir dan batin yang tercantum dalam UndangUndang Nomor I tahun 1974 tentang Perkawinan. Dalam pasal I disebutkan:"Perkawinan adalah ikatan lahir batin antara seorang pria dan wanita sebagai suami istri dengan tujuan membentuk keluarga (rumah tangga) yang bahagia dan kekal berdasarkan Ketuhanan Yang Maha Esa"

${ }^{3} \mathrm{KHI}$ adalah dasar atau asas dan referensi dalam pembentukan Undang-Undang Nomor I Tahun 1974 tentang Perkawinan.
} 
kajian mendalam mengenai kesamaan atau perbedaan yang mendetail mengenai kasus ini dalam kitab Figh Islam Wa Adillatuh dan Kompilasi Hukum Islam.

Memang kontroversi kasus poligami terus mewacana hingga saat ini, karena ada suatu anggapan bahwa poligami masih melecehkan kaum hawa. Bahkan isu gender dalam interelasi pasangan laki-laki dan perempuan menjadi sarat akan muatan politik dan kepentingan sepihak. ${ }^{4}$ Inilah yang menyebabkan poligami dipertanyakan kembali otoritasnya dalam kehidupan rumah tangga. Apakah syarat adil menjadi bagian mutlak dalam legalitas poligami atau hanya istithấah saja yang diperlukan agar memudahkan praktik tersebut.

Di Negara Indonesia, permasalahan poligami ini diberikan aturan secara terperinci dalam Undang-undang Nomor 1 tahun 1974 tentang Perkawinan. Dimana tujuan utama perkawinan adalah membina rumah tangga yang bersifat kekal, dilanjutkan dengan dasar perkawinan adalah monogami yang tertera pada pasal 3. Adapun kriteria berpoligami pada pasal 4 yang menyatakan bahwa pengadilan berhak memberikan izin atau tidak pada seorang suami yang berkeinginan memiliki istri lebih dari satu, dengan beberapa syarat yang harus dipenuhi.

Izin poligami akan diberikan oleh pengadilan apabila: ${ }^{5}$

1. Istri tidak menjalankan sebagai istri

2. Istri mendapat cacat badan atau penyakit yang tidak dapat disembuhkan

3. Istri tidak bisa memberikan keturunan

Secara umum, memang al-Qur'an mengisyaratkan bahwa Allah menciptakan manusia secara berpasangan seperti yang tertera dalam al-Qur'an Surat Yâsin (36): 36, al-Rûm (30): 21, alFurqân (25): 74, Al-Dzâriyyât (51): 49, al-Nahl (16): 72, al-Taubah

\footnotetext{
${ }^{4}$ Alean Al-Krenawi, Psychosocial Impact of Polygamy in the Middle East, (Berlin, Jerman: Springer Science \& Business Media, 2013), 2.

${ }^{5}$ M. Taufan B, Sosiologi Hukum Islam: Kajian Empirik Komunitas Sempalan, (Yogyakarta: Deepublish, 2016), 63.
} 
(9): 71, al-Hujurât (49): 13, Fâthir (35):11, al-Syûrâ (42):11. Mayoritas ayat al-Qur'an memang sangat jelas mengisyaratkan bahwa lakilaki berpasangan dengan perempuan dalam masalah pernikahan. Akan tetapi, ketika mengarah pada berbilangnya pasangan pada al-Qur'an surat al-Nisâ', muncul beberapa prasyarat yang Allah ajukan jika hendak melakukan praktik poligami tersebut.

Pola yang tebilang mudah secara harfiyah tapi berat secara kontekstual membuat ayat ini menjadi bahan khilafiyah oleh para intelektual Muslim dalam mengimplementasikannya. Dimulai dari surat al-Nisâ' ayat 2-3 Allah mengisyaratkan sesuatu yang berbeda dari masalah perkawinan lebih dari satu istri, tapi ada satu isyarat yang menarik untuk dicermati yang artinya sebagai berikut:

"Dan jika kamu khawatir tidak akan mampu berlaku adil terhadap (hak-hak) perempuan yatim (bilamana kamu menikahinya), maka nikahilah perempuan (lain) yang kamu senangi: dua, tiga atau empat. Tetapi jika kamu khawatir tidak akan mampu berlaku adil, maka (nikahilah) seorang saja, atau hamba sahaya perempuan yang kamu miliki. Yang demikian itu lebih dekat agar kamu tidak berbuat zalim." ${ }^{\prime 6}$

Ketika al-Qur'an memberikan pedoman mengenai kebolehan poligami, bukan berarti poligami merupakan keharusan bagi umat Islam secara umum. Hal ini diakui Musdah Mulia, seorang aktifis gender yang mengatakan bahwa pintu poligami merupakan konsep yang sangat darurat jika ingin melakukannya. Poligami yang tertutup ini disebabkan bahwa praktik ini secara umum tidak lagi berlatar al-Qur'an dan perasaan sebagai panduan hukum, melainkan lebih pada nuansa negatif bagi sang perempuan. Itulah mengapa di Indonesia diberikan beberapa persyaratan dalam Undang-undang dan Kompilasi Hukum Islam (KHI) mengenai poligami ini. Bukunya yang berjudul Gender dalam Perspektif Islam sangat detail menjelaskan faktor terdindingnya pintu poligami, diantaranya seperti munculnya permusuhan karena saling cemburu, faktor sosial dalam kehidupan rumah tangga, juga faktor 
ekonomi yang kerap menjadi alasan pertengkaran suami istri. Konsep bijaksana dan adil secara riil diperlukan dalam kasus poligami ini. ${ }^{7}$

Berbeda dengan Euis Nurlaelawati yang meneliti tentang identitas KHI Modernization, Tradition and Identity: The Kompilasi Hukum Islam and Legal Practice in the Indonesian Religious Courts, menyebutkan bahwa poligami merupakan produk Islam dan terus berkembang, tinggal negara yang mengatur sistem yang dihasilkan oleh al-Qur'an untuk dapat diberikan batasan aturan mengenai poligami ini, bukan menghapusnya. Tetapi banyak aturan dan cara yang harus dilakukan jika ingin melegalkan praktik poligami ini melalui beberapa step by step, bukan semudah yang dilihat, karena Indonesia menganut sistem demokrasi berkeadilan untuk menjaga harkat dan martabat perempuan Islam. ${ }^{8}$

Sementara menurut pakar fikih Islam, Wahbah Zuhaili, menyebutkan bahwa poligami merupakan maslahah 'ammah (problem solving) bagi mereka yang mengalami permasalahan sosial dan keluarga yang bersifat kekurangan, terutama mereka yang memiliki libido tinggi bagi lelaki yang hiperseks agar terhindar dari perbuatan zina seksual ataupun krisis akhlak yang bersifat negatif. Hal ini tentu akan mendatangkan kemaslahatan bagi rumah tangga dan rahmat bagi lingkungan bersama, dan yang paling utama dapat mengayomi perempuan dan anak yatim serta terhindar dari menularnya penyakit berbahaya seperti HIV. ${ }^{9}$

7 Teori ini pada akhirnya memunculkan konsep Counter Legal Draft-Kompilasi Hukum Islam (CLD-KHI) yang ingin merevisi pasal tentang perkawinan khususnya poligami. Lihat dalam Musdah Mulia, Gender dalam perspektif Islam, (Jakarta: Kementerian Negara Pemberdayaan Perempuan, 2007), $181-182$.

${ }^{8}$ Euis Nurlaelawati, Modernization, Tradition and Identity: The Kompilasi Hukum Islam and Legal Practice in the Indonesian Religious Courts (Amsterdam: Amsterdam University Press, 20 I0), 196 198.

9 Wahbah Al-Zuhaili, Al Figh Al-Islâm Wa Adillatuh, (Damaskus: Dar-Fikr, 1989), Vol. III, 169. Mashlahah (interest) menurut Wahbah Zuhaili adalah: dharuriyyat is occurring on a single hazardous condition, or hardship which might lead to serious injury or sickness of the soul, causing detrimental to the members, dignity, intellect, or property and everything connected with it. Lihat Harun, "Contemporary Issues and Development in the Global Halal Industry: Selected 
Menurut Wahbah Zuhaili, bahwa konsep poligami jika dilihat dari pendekatan maslahah setidaknya memunculkan dua alasan kenapa Allah memberikan pembatasan dalam poligami. Pertama, suami mampu berlaku adil dalam pendekatan zhahir. Misal suami mampu memberikan nafkah, pembagian waktu yang sesuai dengan surat al-Nisâ ayat 3 di atas dalam menunaikan hak istri dan anak-anaknya. Kedua, sanggup membayar nafkah belanja rumah tangganya sehingga semuanya merasa nyaman dan tenteram dalam menjalankan kehidupannya. ${ }^{10}$ Sesuai dengan Sabda Rasulullah Saw tentang perlu adanya biaya dalam rumah tangga (al-ba'ah) bagi calon suami. ${ }^{11}$

Kajian ini pada akhirnya membuat penulis ingin melihat relevansi ayat ke 3 dan ayat ke 129 surat al-Nisâ mengenai aturan dan legalitas berpoligami yang dilihat dari prasyarat "sanggup" berpoligami dari teori maslahah Wahbah Zuhaili dalam karyanya Figh al-Islâm wa Adillatuh bab al-Nikâh dan melalui Kompilasi Hukum Islam (KHI).

\section{Poligami: Problematika antara Teks dan Konteks}

Poligami berasal dari bahasa Yunani yang merupakan gabungan kata poli atau polus yang artinya banyak, dan gamen atau gamos yang berarti kawin atau perkawinan. Maka ketika kedua kata ini digabungkan akan berarti suatu perkawinan yang banyak. Kalau dipahami dari kata ini, menjadi sah untuk mengatakan bahwa arti poligami adalah perkawinan banyak, dan bisa jadi dalam jumlah yang tak terbatas. ${ }^{12}$

\footnotetext{
...," Springer, accessed May 30, 2017, 288. Di bagian lain mashlahah diartikan dengan bagian tharuriyyaat (necessity), lihat juga pendapatnya dalam Abdul Hamid Abu Sulayman, Towards an Islamic Theory of International Relations: New Directions for Islamic Methodology and Thought (International Institute of Islamic Thought (IIIT), 1987). 165

${ }^{10}$ Al-Zuhaili, Al Fiqh Al-Islâm Wa Adillatuh..., 161

"Khaeron Sirin, Perkawinan Mazhab Indonesia: Pergulatan antara Negara, Agama, dan Perempuan, (Yogyakarta: Deepublish, 2016), 38-39.

12 Khoiruddin Nasution, Riba dan Poligami: Sebuah Studi Atas Pemikiran Muhammad Abduh, (Yogyakarta: Pustaka Pelajar, 1996), 84.
} 
Poligami menurut Kamus Besar Bahasa Indonesia adalah ikatan perkawinan yang salah satu pihak memiliki atau mengawini beberapa lawan jenisnya dalam waktu bersamaan. ${ }^{13}$ Secara istilah poligami memiliki arti, perbuatan seorang laki-laki mengumpulkan dalam tanggungannya dua sampai empat orang istri dan tidak boleh lebih dari itu. ${ }^{14}$ Sedangkan pengertian poligami menurut syariat Islam ialah, kata poligami atau ta'addud az-zaujat mempunyai arti seorang laki-laki diperbolehkan mengawini perempuan sebanyak dua, tiga, atau empat jika mampu berlaku adil. Jumhur ulama berpendapat bahwa batasannya yaitu hanya empat. ${ }^{15}$

Poligami secara terminologi Islam memiliki arti perbuatan seorang laki-laki mengumpulkan dalam tanggungannya dua sampai empat orang istri, dan tidak boleh lebih dari itu. ${ }^{16}$ Poligami dalam artian ini menunjukkan bahwa mereka yang ingin memiliki lebih dari satu istri harus memiliki ikatan akad secara syariat Islam dan sesuai dengan aturan negara. ${ }^{17}$ Syariat yang diturunkan dengan suatu kebolehan berpoligami menunjukkan bahwa syariat tersebut memiliki suatu tujuan terentu, yaitu mengikuti ketentuan syariat poligami. ${ }^{18}$ Pola sebab-akibat yang dituangkan dalam surat al-Nisâ' ayat 3 dan 129 ini menunjukkan bahwa pola praktik poligami akan menjadi harmonis jika mengikuti aturan syariat Islam dalam menjalankannya untuk kemaslahatan rumah tangga dan lingkungan.

Kajian di atas menunjukkan bahwa praktik poligami memiliki peranan penting dalam memperbaiki tatanan strata sosial

\footnotetext{
${ }^{13}$ Khoiruddin Nasution, Riba dan Poligami..., 169.

${ }^{14}$ Arij Abdurrahman Sanan, Memahami Keadilan dalam Poligami, (Jakarta: Globalmedia Cipta Publishing, 2003), 25.

${ }^{15}$ Abd Kadir Syukur, Hukum Perkawinan di Indonesia, Ist ed., (Barito Kuala KalSel: LPKU, 20I5), 160.

${ }^{16}$ Arij Abdurrahman Sanan, Memahami Keadilan dalam Poligami..., 25

${ }_{17}$ Endang Saifuddin Anshari, Piagam Jakarta, 22 Juni 1945: Sebuah Konsensus Nasional Tentang Dasar Negara Republik Indonesia (1945-1959), (Jakarta: Gema Insani, 1997), 2-3.

${ }_{18}$ Miriam Koktvedgaard Zeitzen, Polygamy: A Cross-Cultural Analysis, (London: A\&C Black, 2008), 21.
} 
masyarakat bagi mereka yang memiliki kekurangan dalam berumah tangga. Oleh karena itu, dapat dikatakan bahwa berpoligami merupakan suatu perbuatan rukhshah (kemudahan), karena merupakan rukhshah, maka hanya bisa dilakukan dalam keadaan darurat, yang benar-benar mendesak dan tidak mengakibatkan ketidakadilan dalam melakukannya. ${ }^{19}$

Ketika Allah Swt memberikan izin kebolehan untuk melakukan poligami dengan memberikan sampai empat orang istri, Allah Swt juga memberikan sebuah teks aturan untuk menjalankannya. Aturan tersebut dimulai dari kebolehan pernikahan yang dilandasi ketakwaan dan menghilangkan kemudharatan.

Dalam Surat An-Nisâ' ayat 129 yang artinya:

“Dan kamu tidak akan dapat berlaku adil di antara istri-istri(mu), walaupun kamu ingin berbuat demikian, karena itu janganlah kamu terlau cenderung (kepada yang kamu cintai) sehingga kamu biarkan yang lain terkatung-katung. Dan jika kamu mengadakan perbaikan dan memelihara diri (dari kecurangan), maka sungguh Allah Maha Pengampun, Maha Penyayang."

Ayat tersebut menegaskan bahwa keadilan tidak mungkin dapat dicapai jika berkaitan dengan perasaan atau hati dan emosi cinta. Keadilan yang harus dicapai adalah keadilan materi sematamata, sehingga seorang suami yang poligami harus menjamin kesejahteraan istri-istrinya dan mengatur waktu gilir secara adil..$^{20}$

Sejak masa Rasulullah Saw, Sahabat, Tabi'in, periode ijtihad dan setelahnya sebagian besar kaum Muslimin memahami dua ayat akhkam yaitu surat an-Nisâ' ayat 3 dan 129 itu sebagai berikut: ${ }^{21}$

1. Perintah Allah SWT, "maka kawinilah wanita-wanita (lain) yang kamu senangi", difahami fi'il amar (kata perintah) fankihû sebagai

\footnotetext{
${ }^{19}$ Sayyid Quthb, Fi Zhilalil Quran, (Beirut: Lebanon: Dar Syuruq, 1994), 275-276

${ }^{20}$ Abdul Aziz ibn Fauzan ibn Shalih, Fikih Sosial: Tuntunan dan Etika Hidup Bermasyarakat, (Jakarta: Qisthi Press, 2016), 178.

${ }^{21}$ Agil Fitra Muhshy Paradana Hartama et al., "Pertimbangan Hakim dalam Perkara ljin Poligami (Studi Kasus Putusan Nomor II87/Pdt. G/2013/PA Bpp.)", (Universitas Muhammadiyah Surakarta, 2016), http://eprints.ums.ac.id/42080/, 17-19.
} 
perintah ibâhah (boleh), bukan wajib. Pilihan boleh ini menunjukkan memiliki hak untuk lebih dari satu tapi dianjurkan tetap satu jika tidak mampu. Ahli bahasa dan tafsir juga sepakat bahwa ayat tersebut sifatnya memiliki batas diperbolehkan. ${ }^{22}$

2. Poligami berlaku seperti halnya pernikahan yang memiliki jangka dan waktu dalam akad dan bersifat darurat bukan karena nafsu atau keinginan memperkaya diri.

3. Asas keadilan bukan hanya dilihat dari kesiapan dan mampu dari segi ekonomi saja (nafkah), melainkan mampu memenuhi dan menyenangkan istri-istrinya dan tidak berperilaku zhalim. Jika hal tersebut terjadi, maka lebih baik satu istri saja. Sebagaimana firman Allah, "Kemudian jika kamu takut tidak akan berlaku adil, maka (kawinilah) seorang saja, atau budak-budak yang kamu miliki".23

4. Mafhum mukhâlafah dari syarat adil tersebut adalah jika muncul kekhawatiran tidak bisa berlaku adil dalam memenuhi hak-hak istri yang kawin lebih dari satu, maka asas monogami wajib. Bila tetap memaksakan diri, maka ia berdosa meskipun perkawinannya tetap sah. ${ }^{24}$

Adapun mengenai dalil dari sunnah tentang poligami memang tidak ada yang menerangkan bahwa poligami itu harus dan dianjurkan dalam perkawinan. Hal ini dikarenakan sudah ada penjelasannya dalam surat al-Nisâ' ayat 4 tersebut, akan tetapi Rasulullah Saw memberikan peringatan bagi mereka yang

22 Lihat dalam Dee Hazim, Polygamy Preppers Guide: Five Fictional Stories about What Can Happen If You Are Caught Unprepared for a Polygamy Storm. Lust, Betrayal, Sex, Violence, Mayhem, (Bloomington: Xlibris Corporation, 2014). Lihat juga dalam Gunawan Adnan, Women and the Glorious Qur'ân: An Analytical Study of Women-Related Verses of Sûra An-Nisa' (Universitätsverlag Göttingen, 2004), 192-193. Sementara R. Saija lebih menekankan bahwa asas monogami lebih terbuka karena ayat ke 4 tersebut ditutup dengan konsep di ayat 129 dengan ketidakmampuan manusia untuk berpoligami, bandingkan R. Saija and lqbal Taufik, Dinamika Hukum Islam Indonesia (Yogyakarta: Deepublish, 2016), 53-54.

${ }^{23}$ Huzaimah T. Yango, Zaitunah Subhan (Ed), Membendung liberalisme, (Jakarta: Penerbit Republika, 2006), 95.

24 Fada Abdul Razak Al-Qoshir, Wanita Muslimah Antara Syari'at Islam dan Budaya Barat (Yogyakarta: Darussalam Offset, 2004), 42-45 
mempraktikannya dengan beberapa sanksi yang akan diterimanya jika tidak berlaku adil dalam rumah tangganya. Rasulullah Saw bersabda yang artinya: "Barangsiapa yang mempunyai dua orang isteri lalu cenderung kepada salah satu dari keduanya dibandingkan yang lainnya, maka dia datang pada hari Kiamat dengan menarik salah satu dari kedua pundaknya dalam keadaan jatuh atau condong". 25

Dari beberapa hadits yang menerangkan mengenai aturan berpoligami, menurut Firdaus dalam penelitiannya tentang makna hadits-hadits poligami, menyatakan bahwa ada sekitar 83 riwayat yang menjelaskan tentang praktik poligami. Hasil temuannya menyatakan bahwa dalam hadits tentang poligami, Nabi menekankan asas keadilan dengan nafkah dan etika berpoligami, suruhannya bukan dalam bentuk perintah atau anjuran, melainkan hanya kebolehan melakukannya dengan berbagai prasyarat yang sangat ketat seperti pertimbangan kemampuan adil dan kemaslahatan. Tujuannya untuk menghindarkan dari praktik patriarki dan menghapus ketidakadilan gender yang memarginalkan para perempuan. Melalui telaah kehidupan Nabi Saw., Beliau tidak melakukan poligami karena dorongan syahwat, seperti dakwaan Barat, karena menurut kajian ilmiah kedokteran, bahwa nafsu seksual laki-laki menurun pada usia 50 tahun, dan itupun dilakukan setelah sayyidah Khadijah wafat atas perintah Allah Swt atas pertimbangan kemanusian dan maslahat umat. ${ }^{26}$

Ada sebagian mufassir yang menafsirkan al-Qur'an surat alNisâ' ayat 3 dengan jalan menambahkan, yaitu satu ditambah dua ditambah 3 ditambah 4, maka jumlah wanita yang boleh dinikahi menjadi sembilan. ${ }^{27}$ Bahkan ada yang berpendapat, bahwa cara

\footnotetext{
25 R. At-Tirmidzi (no. II4I) kitab an-Nikâh, an-Nasâ-i (no. 3942) kitab 'Isyratun Nisâ', Abu Dawud (no. 2133) Kitab an-Nikâh, Ibnu Majah (no. 1969) kitab an-Nikâh, Ahmad (no. 9740).

${ }^{26}$ Firdaus, "Telaah Kritis Hadis-Hadis Poligami" (Disertasi-Universitas Islam Negeri Syarif Hidayatullah, Jakarta, 2008). Bandingkan dengan kajiannya Jeffrey D. Nichols, Prostitution, Polygamy, and Power: Salt Lake City, $1847-1918$ (University of Illinois Press, 2002), 14.

27 Zainal Arifin, "Jumlah Perempuan yang Boleh Dipoligami Kajian Terhadap Al-Qur'an Surat AlNisa'ayat 3," Journal Analytica Islamica, Volume I, Nomor 2 (20 I2), 242-257.
} 
penjumlahannya dengan menghitung dua ditambah dua, ditambah tiga ditambah tiga, ditambah empat ditambah empat, maka jumlahnya menjadi delapan belas. ${ }^{28}$

Untuk mereka yang berpendapat bisa menikahi sembilan wanita, disamping didukung dengan cara penjumlahan sebagaimana disebutkan di atas, dan jalan inilah menurut mereka yang disebutkan dalam Al-Qur'an, juga didukung dengan perbuatan Nabi sendiri, yang pernah mempunyai istri sembilan dalam waktu yang bersamaan. Padahal, kata mereka menambahkan, mengikuti perbuatan Nabi merupakan satu kewajiban yang harus dilakukan. Hal ini didasarkan pada statemen Al-Qur'an sendiri yang mengatakan bahwa Nabi adalah contoh teladan (uswatun hasanah), yang harus dicontoh pengikut (umatnya).

Sedang hubungannya dengan perbuatan Nabi, sebagaimana dijadikan salah satu alasan, juga ada beberapa hal yang penting dicatat. Pertama, melihat fakta sejarah pernikahan Nabi, yang pada mulanya Nabi mempunyai istri hanya satu (monogamy), yaitu Siti Khadijah sampai 25 tahun lamanya. Beliau mempunyai istri lebih dari satu atau bahkan lebih dari empat setelah beliau berumur di atas 50 tahun. ${ }^{29}$ Kalau memang Rasulullah ingin melakukan poligami dengan keinginannya sendiri, bukan karena hal lain yang lebih penting dari sekedar kebutuhan biologis, mestinya beliau menikahi wanita yang cantik-cantik di masa mudanya.

Sebaliknya, kenyataan menunjukkan bahwa wanita yang beliau nikahi, umumnya berstatus pernah menikah, dan hanya 'Aisyah yang masih perawan, dan itupun dinikahi ketika masih

\footnotetext{
${ }^{28}$ Sebagian menyebutkan bahwa ini adalah golongan Rafidhah dan sebagian Ahlu Zhahir yang mengatakan tetap boleh 18 orang dengan sistem hitungan tersebut. Lihat Agus Sunaryo, "Poligami di Indonesia (Sebuah Analisis Normatif-Sosiologis)," Yin Yang, Volume 5, Nomor I (2010), I43167. Khaeron Sirin, Perkawinan Mazhab Indonesia.... 39-40.

${ }^{29}$ Bandingkan dengan Sofyan, "Analisis Pemikiran Musdah Mulia Terhadap Keharaman Poligami," Bil Dalil, Volume I, Nomor 02 (2017), I-28. Lihat juga dalam Usman, "Perdebatan Masalah Poligami dalam Islam (Kajian Tafsir Al-Maraghi QS. Al-Nisâ' ayat 3 dan 129)", Anida' , Volume 39, Nomor I (20 I4), I3I.
} 
berumur enam tahun, ${ }^{30}$ dengan ungkapan lain, pernikahan beliau lebih disebabkan oleh faktor yang lebih penting bagi umat Islam ketika itu, bukan dari kebutuhan biologis ${ }^{31}$. Kedua, perlu diingat, bahwa ternyata ada hal-hal yang khusus hanya berlaku kepada Nabi Muhammad Saw, bukan diperuntukkan secara umum untuk umat Islam. Hal ini dengan jelas disebutkan dalam Al-Qur'an, ${ }^{32}$ misalnya disebut di surat Al-Ahzâb ayat 51-52 mengenai aturan dan khususiyyah Rasul. ${ }^{33}$

\section{Dasar Sosial Kebolehan Poligami}

Secara umum, al-Qur'an dan hadits memperbolehkan praktik poligami ini. Dari pendekatan sosial ada beberapa keadaan secara sosial masyarakat yang merupakan pemecahan terbaik bagi diperbolehkannya poligami.

1) Bila istri menderita suatu penyakit yang berbahaya seperti lumpuh, ayan atau penyakit menular. Dalam keadaan ini, maka akan lebih baik bila ada istri yang lain untuk memenuhi dan

\footnotetext{
30 Holilur Rohman, "Batas Umur Pernikahan Dalam Perspektif Hukum Islam: Studi Penerapan Teori Maslahah Mursalah" (UIN Sunan Ampel Surabaya, 2009), http://digilib.uinsby.ac.id/id/eprint/7389, 46-47.

${ }^{31}$ Aris Baidhowi, "Hukum Poligami dalam Persepektif Ulama Fiqh." Muwazah, Volume 4, Nomor I (20 I3). http://e-journal.iainpekalongan.ac.id/index.php/Muwazah/article/view/I 49, 6 I -62.

32 Khoiruddin Nasution, Riba \& Poligami..., 91

${ }^{33}$ Artinya: "Wahai nabi, sesungguhnya Kami menghalalkan untukmu, istri-istri yang telah engkau berikan maharnya, dan budak-budak wanita kepunyaanmu yang berasal dari daerah orang-orang kafir yang telah kalah dalam peperangan, dan anak saudara laki-laki ibumu, dan anak saudarasaudara perempuan ibumu yang sudah bersama-sama hijrah denganmu, dan juga seorang wanita yang beriman, kalau ia menyerahkan dirinya kepada Nabi, jika Nabi mau menikahinya, sebagai peraturan yang khususu untukmu, dan tidak berlaku untuk kaum Muslimin yang lain. Kami sudah mengetahui apa yang kami wajibkan kepada mereka terhadap istri-istri dan budak-budak mereka, agar engkau tidak merasa janggal; dan Allah Maha Pengampun Maha Pengasih. Engkau boleh menangguhkan untuk mengadakan hubungan dengan siapa yang engkau kehendaki di antara mereka, dan boleh juga mengadakan dengan siapa engkau ingin menghubunginya (menggaulinya) kembali setelah tadinya engkau ceraikan, maka tidak ada halangan bagimu untuk menghubunginya kembali. Itulah cara yang lebih dekat untuk menenangkan hati mereka, dan agar mereka tidak merasa sedih, dan mereka semuanya menjadi rela terhadap apa yang telah engkau perbuat kepada mereka. Dan Allah mengetahui apa yang tersimpan di dalam hatimu. Dan Allah adalah Maha Mengetahui dan Maha Penyantun."
} 
melayani berbagai keperluan si suami dan anak-anaknya. Kehadirannya pun akan turut membantu istri yang sakit itu. ${ }^{34}$

2) Bila si istri terbukti mandul dan setelah melalui pemeriksaan medis, para ahli berpendapat bahwa dia tak dapat hamil, maka sebaiknya suami menikah lagi untuk mendapatkan istri kedua sehingga dia mungkin akan memperoleh keturunan, karena anak merupakan permata kehidupan. ${ }^{35}$

3) Bila istri sakit ingatan. Dalam hal ini tentu suami dan anakanak sangat menderita.

4) Bila istri telah lanjut usia dan sedemikian lemahnya sehingga tak mampu memenuhi kewajibannya sebagai seorang istri, memelihara rumah tangga dan melayani suaminya.

5) Bila suami mendapatkan bahwa istrinya memiliki sifat yang buruk dan tak dapat diperbaiki, maka secepatnya dia menikahi istri yang lain.

6) Bila dia minggat dari rumah suaminya dan membangkang sedangkan si suami merasa sakit untuk memperbaikinya. ${ }^{36}$

7) Pada masa perang dimana kaum lelaki terbunuh meninggalkan wanita yang sangat banyak jumlahnya, maka poligami dapat berfungsi sebagai jalan pemecahan terbaik.

8) Selain hal-hal tersebut di atas, bila lelaki itu merasa bahwa dia tak dapat bekerja tanpa adanya istri kedua untuk memenuhi hajat syahwatnya yang sangat kuat serta dia memiliki harta yang cukup untuk membiayai, maka sebaiknya dia mengambil istri yang lain. ${ }^{37}$

\section{Poligami dalam Kitab Fiqh al-Islam Wa Adilatuh}

Wahbah Zuhaili memberikan definisi bahwa poligami itu diperbolehkan dalam rumah tangga, akan tetapi melalui beberapa tahap syarat "mampu" seperti dalam naskah kitab Figh al-Islam wa

\footnotetext{
${ }^{34}$ Aris Baidhowi, "Hukum Poligami dalam Persepektif Ulama Fiqh," 65-66.

35 Hartama et al., "Pertimbangan Hakim dalam Perkara ljin Poligami (Studi Kasus Putusan Nomor I | 87/Pdt. G/2013/PA Bpp.)." |3-14.

${ }^{36}$ Usman, "Perdebatan Masalah Poligami dalam Islam (Kajian Tafsir Al-Maraghi QS. Al-Nisa'ayat 3 Dan 129)," 333.

${ }^{37}$ Abdul Rahman, Perkawinan Dalam Syariat Islam, (Jakarta: PT. Rineka Cipta, 1996), 49-50.
} 
Adillatuh ${ }^{38}$ bahwa aturan agama telah menetapkan adanya dua syarat diperbolehkannya berpoligami, menurut kitab fiqih Islam ini yaitu:

Syarat yang pertama adalah adanya "sikap keadilan bagi istri". Artinya ialah keadilan yang dilakukan oleh seorang suami itu haruslah berlaku merata bagi para istri-istrinya baik berupa materi, maupun dari segi nafkah baik lahir maupun batin. Hal ini berdasarkan dengan firman Allah SWT dalam surat An-Nisâ' ayat 3 yang artinya sebagai berikut:

“Kemudian jika kamu takut tidak akan dapat berlaku adil, maka (kawinlah) seorang saja, atau budak-budak yang kamu miliki.

Yang demikian itu adalah lebih dekat kepada tidak berbuat aniaya."

Meskipun Allah memberikan izin berpoligami, akan tetapi Allah memberikan suatu ancaman hardikan bagi yang akan berpoligami seperti dalam surat an-Nisâ ayat 4. Kalimat "lan" dalam ayat tersebut menunjukkan bahwa manusia tidak akan mampu berbuat adil terhadap para istrinya meskipun sudah berusaha maksimal karena akan muncul perasaan condong memilih yang lebih di antara para istrinya.

Sesungguhnya Allah SWT memerintahkan hambanya untuk memiliki satu istri saja, apabila dia khawatir tidak mampu untuk bersikap adil di antara para istri. Kemudian penulis mengutip dari pendapat Sayyid Quthb, bahwasanya beliau menerangkan keadilan yang dituntut disini ialah adil dalam bermuamalah, nafkah, pergaulan dan berhubungan. Adapun keadilan berupa cinta dan kasih sayang, Sayyid Quthb berpendapat bahwa tidak seorang pun yang dituntut untuk melakukannya. ${ }^{39}$

Kemudian syarat yang kedua ialah "adanya pemberian nafkah". Secara syariat, syarat ini berarti tidak boleh melakukan perkawinan baik satu istri maupun lebih kecuali dengan adanya

\footnotetext{
${ }^{38}$ Wahbah al-Zuhaili, Figh al-Islam wa Adillatuh, (Beirut: Dar al-Fikr, 2004), Vol. 9, 6669.

${ }^{39}$ Sayyid Quthb, Tafsir Fi Zhilalil Quran Di Bawah Naungan A-Quran, vol. 2, 2 vols. (Jakarta: Gema Insani, 20 I0), 280.
} 
kemampuan untuk membiayai keperluan hidup bagi sang istri. Dalam hal ini, suami wajib untuk memberikan biaya hidup kepada istrinya dalam hal makanan, pakaian, kediaman, serta beberapa kebutuhan pokok lainnya. Nafkah dalam bentuk ini wajib hukumnya berdasarkan al-Qur'an, as-Sunnah, dan ijma' ulama' ${ }^{40}$

\section{Poligami dalam Kompilasi Hukum Islam}

Kompilasi Hukum Islam (KHI) pada awalnya merupakan suatu rujukan hukum agama Islam di Indonesia. Sejarah menyebutkan sejak diputuskan ditetapkan 13 kitab fikih sebagai referensi hukum materiil di Pengadilan Agama melalui Surat Edaran Kepala Biro Pengadilan Agama RI. No. B/1/735 tanggal 18 Februari 1985. Kemudian dibentuklah tim pelaksana dari Surat Keputusan Bersama (SKB) Ketua Mahkamah Agung RI dan Menteri Agama RI No.07/KMA/1985 untuk menyusun fikih menjadi referensi utama dalam pembentukan aturan hukum dalam Undang-Undang Nomor 1 Tahun 1974. ${ }^{41}$

Posisi KHI yang dilanjutkan dengan munculnya instruksi Presiden No. 1 Tahun 1991 sebagai bahan dasar dari putusan di peradilan. ${ }^{42}$ Hadirnya KHI di Indonesia dapat dikatakan sebagai penyeimbang putusan peradilan yang berhubungan dengan keagamaan di Peradilan Agama. Ada catatan menarik dalam penyusunan Kompilasi Hukum Islam di Indonesia hingga akhirnya disetujui sebagai bagian dasar dalam putusan pengadilan, yaitu: ${ }^{43}$

\footnotetext{
${ }^{40}$ Wahbah Az-Zuhaili, Fiqih Islam 9, I st ed. (Jakarta: Gema Insani, n.d.), I62-163

${ }^{41}$ A. Asril, "Eksistensi Kompilasi Hukum Islam Menurut Undang-Undang Nomor 12 Tahun 201 I Tentang Pembentukan Peraturan Perundang-Undangan," Hukum Islam, Volume 15, Nomor I (20I5): 28-45, 29-30. Lihat juga dalam Widya Santika Wahyu Putri And Others, "Kedudukan Hukum Hak Waris Orang Yang Memiliki Kelamin Ganda (Khuntsa Musykil) Ditinjau Dari Instruksi Presiden Nomor I Tahun 199| Tentang Kompilasi Hukum Islam Dan Fatwa Mui" (Fakultas Hukum Unpas, 2017), Http://Repository.Unpas.Ac.ld/ld/Eprint/27463. 30-32.

42 Abdul Gani Abdullah, Pengantar Kompilasi Hukum Islam dalam Tata Hukum Indonesia (Jakarta: Gema Insani, 1994), 62-65

${ }^{43}$ Sulistyowati Irianto, Perempuan dan Hukum: Menuju Hukum Yang Berperspektif Kesetaraan dan Keadilan : 22 Tahun Konvensi CEDAW di Indonesia (Jakarta: Yayasan Obor Indonesia, 2006), 142.
} 
a. Untuk berlakunya hukum Islam di Indonesia, harus ada antara lain hukum yang jelas dan dapat dilaksanakan oleh aparat penegak hukum maupun oleh masyarakat.

b. Persepsi yang tidak seragam tentang syari'ah.

Menurut KHI ada beberapa pasal yang menjelaskan persyaratan yang harus dilakukan oleh suami ketika ingin berpoligami di antaranya:

\section{Pasal 55}

(1) Beristri lebih satu orang pada waktu bersamaan, terbatas hanya sampai empat istri.

(2) Syarat utama beristri lebih dari seorang, suami harus mampu berlaku adil terhadap istri-istri dan anak-anak mereka.

(3) Apabila syarat utama yang disebut pada ayat (2) tidak mungkin dipenuhi, suami dilarang beristri lebih dari seorang.

Jadi, menurut KHI pasal 55 ini menjelaskan bahwa lakilaki yang hendak berpoligami tidak diperbolehkan mengawini lebih dari empat orang istri, kemudian syarat utama untuk berpoligami ialah suami harus mampu berlaku adil bagi istri dan anak-anaknya, yang dimaksud adil disini ialah mampu memberikan biaya keperluan untuk kehidupan sehari-hari kepada anak istrinya, kemudian apabila syarat utama tidak dapat dipenuhi, maka seorang suami dilarang untuk melakukan perkawinan lagi.

Disini penulis menemukan kesamaan antara syarat utama yang ada pada kitab Figh al-Islam wa Adillatuhu dengan KHI ini, yaitu sama-sama menitikberatkan kepada perlakuan adil suami serta pemberian nafkah yang dia berikan kepada keluarganya.

\section{Pasal 56}

(1) Suami yang hendak beristri lebih dari satu orang harus mendapat izin dari Pengadilan Agama. 
(2) Pengajuan permohonan izin yang dimaksud pada ayat (1) dilakukan menurut tata cara sebagaimana diatur dalam Bab VIII Peraturan Pemerintah No.9 Tahun 1975.

(3) Perkawinan yang dilakukan dengan istri kedua, ketiga, atau keempat tanpa izin dari Pengadilan Agama, tidak mempunyai kekuatan hukum.

Menurut pasal 56, ada penambahan persyaratan formil yang harus dilakukan seorang suami ketika ingin berpoligami antara lain ialah harus mendapat izin terlebih dahulu kepada Pengadilan Agama, sedangkan yang penulis ketahui bahwa di kitab Figh alIslam wa Adillatuhu, izin dari Pengadilan Agama tersebut tidak dijadikan suatu syarat utamanya.

\section{Pasal 57}

Pengadilan Agama hanya memberikan izin kepada seorang suami yang akan beristri lebih dari seorang apabila:

a. Istri tidak dapat menjalankan kewajiban sebagai istri.

b. Istri mendapat cacat badan atau penyakit yang tidak dapat disembuhkan.

c. Istri tidak dapat melahirkan keturunan.

Pada pasal 57 huruf $\mathrm{b}$ dan $\mathrm{c}$ ini penulis menemukan kesamaan pembolehan poligami kepada suami dengan pembolehan yang ada di kitab Figh al-Islam wa Adillatuhu yaitu sama-sama membolehkan berpoligami apabila dari pihak istri mendapat kecacatan, suatu penyakit yang tidak dapat disembuhkan, dan istri tidak dapat memberikan keturunan.

Dari beberapa point di atas penulis juga memukan beberapa hal diperbolehkannya berpoligami yang serupa dalam tafsir AlMarâghi antara lain ialah: tidak mempunyai anak yang akan menyambung keturunan, dan istri pertama menderita penyakit menahun (kronis) yang tidak memungkinkannya melakukan tugas sebagai istri. ${ }^{44}$

${ }^{44}$ Ahmad Mustafa al-Maragi, Tafsir al-Maragi Juz 4, (Bahrun Abu Bakar dan Hery Noer ali, Tafsir al-Maragi), (Semarang: CV. Toha Putra Semarang, 1993), 326-327. 
Pasal 58

(1) Selain syarat utama yang disebut pada pasal 55 ayat (2) maka untuk memperoleh izin Pengadilan Agama, harus pula dipenuhi syarat-syarat yang ditentukan pada Pasal 5 Undang-Undang No. 1 Tahun 1974 yaitu:

a. Adanya persetujuan istri

b. Adanya kepastian bahwa suami mampu menjamin keperluan hidup istri-istri dan anak-anak mereka

(2) Dengan tidak mengurangi ketentuan pasal 41 huruf $b$ Peraturan Pemerintah No. 9 Tahun 1975, persetujuan istri atau istri-istri dapat diberikan secara tertulis atau dengan lisan, tetapi sekalipun telah ada persetujuan tertulis, persetujuan ini dipertegas dengan persetujuan lisan istri pada sidang Pengadilan Agama.

(3) Persetujuan dimaksud pada ayat (1) huruf a tidak diperlukan bagi seorang suami apabila istri atau istriistrinya tidak mungkin dimintai persetujuannya dan tidak dapat menjadi pihak dalam perjanjian atau apabila tidak ada kabar dari istri atau istri-istrinya sekurangkurangnya 2 tahun atau karena sebab lain yang perlu mendapat penilaian Hakim..$^{45}$

Pada pasal 58 ayat (1) huruf a ini syarat utama untuk melakukan poligami bagi sang suami ialah dengan adanya persetujuan istri, kemudian pada ayat (2) persetujuan tersebut dapat diberikan secara lisan maupun tertulis yang kemudian dihadapkan di persidangan. Kembali lagi penulis menemukan perbedaan antar pasal-pasal yang ada di KHI ini dengan yang ada di kitab Figh al-Islam wa Adillatuhu, yang mana persetujuan istri bukanlah syarat utama bagi seorang suami yang ingin berpoligami.

${ }^{45}$ Undang-Undang Republik Indonesia Nomor I Tahun 1974 Tentang Perkawinan Dan Kompilasi Hukum Islam, (Cetakan I: Grahamedia Press, 20I4), 348-349. 


\section{Konsep Prasyarat Poligami Pendekatan Mashlahah Mursalah}

\section{Kaedah Penggunaan Mashlahah Mursalah}

Sebenarnya banyak sekali dari para ulama yang mencoba untuk menggunakan konsep istishlah ini, di antara ulama yang paling longgar dalam menggunakannya adalah Imam Malik dan dikutip kembali oleh Wahbah Zuhaili dalam pengembangannya. ${ }^{46}$ Argumen penggunaan maslahah dalam masalah mualamah adalah: Pertama, ada keselarasan antara mashlahah yang dijadikan sebagai dasarnya dengan maqâsid syari'ah, dan tidak bertentangan dengan dalil qath'i demi mewujudkan kemaslahatan dan menolak kemudaratan. Kedua, dapat diterima akal sehat dan berdasarkan fakta yang nampak. Ketiga, dalam penggunaan mashlahah tersebut dapat menghilangkan kesusahan yang bersifat umum, yaitu dapat mewujudkan manfaat bagi orang lain dan tidak ada yang merasa dirugikan dalam pengamalannya. ${ }^{47}$ Teori Mashlahah dari Wahbah Zuhaili memiliki karakter yang bersifat umum dan tidak merugikan lingkungan sekitar, bersifat kenyataan dan tidak ada rekayasa publik, tidak bertentangan dengan pokok utama alQur'an dan hadits, serta tidak memberikan mudarat pada orang lain dan diri sediri.48

\section{Mashlahah Poligami menurut Wahbah Zuhaili}

Menurut Wahbah Az-Zuhaili dalam kitabnya menyebutkan bahwa secara garis besar persyaratan poligami hanya ada dua saja. Pertama, keadilan bagi para istri atau anak-anak mereka. Kedua, seorang suami harus mampu memberi nafkah. Akan tetapi, pada bahasan selanjutnya ia memaparkan tentang sebab-sebab dibolehkannya poligami, diantaranya untuk mengatasi persoalan

\footnotetext{
${ }^{46}$ Muhammad Musthafa Shalabi, Al-Madkhal Fi Al-Figh Al Islamy, IOth ed. (Beirut, Lebanon: Dar al Jami'ah, I 405), 256.

47 Shalabi, Al-Madkhal Fi Al-Figh Al Islamy, 270. Bandingkan dengan Aminudin Slamet Widodo, "Konsep Maslahah Mursalah Wahbah Zuhaili dan Relevansinya dengan Pernikahan Sirri di Indonesia" (UIN Maulana Malik Ibrahim Malang, 20I I), 59.

${ }^{48}$ Secara tersirat terdapat beberapa konsep maslahat (al-mashlahah) versi Wahbah Zuhaili yang kesemuanya menekankan pada faktor sekitar sebagai acuan dalil sebuah hujjah dalam beribadah muamalah. Lihat dalam Al-Zuhaili, Al Figh Al-Islam Wa Adillatuh. Vol 9, 163, 173, 175, 206, 339, $365,462,464$, dan 520 .
} 
banyaknya kaum perempuan dan sedikitnya kaum laki-laki. Baik dalam kondisi yang biasa, akibat bertambahnya populasi kaum perempuan, atau setelah terjadinya peperangan.

Dalam surat An-Nisâ' ayat 3, al-Qur'an memberikan sebuah prasyarat dalam poligami, yaitu jika dirasa tidak mampu, maka cukup satu istri saja. Kajian mencari yang terbaik dalam suatu rumah tangga juga menjadi rumusan penting dalam pembentukan mashlahah versi Wahbah yang mengisyaratkan bahwa poligami merupakan rukhshah baina dhararain artinya diperbolehkan jika sudah mengetahui prasyarat poligami dan praktiknya. Tapi jika itu mengalami halangan dan rintangan, maka sangat afdhal cukup satu istri.

Kemudian pada pembahasan selanjutnya, Wahbah Az-Zuhaili memaparkan pendapatnya tentang sebab-sebab khusus dibolehkannya poligami yaitu kemandulan istri, atau adanya penyakit, atau tabiatnya tidak sejalan dengan tabiat suaminya. Dalam hal ini penulis menemukan keselarasan antara pendapat Wahbah Az-Zuhaili dengan pasal 57 huruf b dan c Kompilasi Hukum Islam yang mana pada persyaratan itu pengadilan agama dapat memberikan izin kepada seorang suami untuk beristri lebih dari satu orang apabila seorang istri ada cacat atau penyakit yang tidak bisa disembuhkan dan istri tidak dapat melahirkan. Maka alangkah baiknya serta untuk menjaga nama baik, jika si istri terus berada dalam ikatan perkawinan, karena hal ini lebih mulia untuknya, dan lebih ia sukai. Lalu dia berikan izin kesempatan kepada suaminya kawin dengan perempuan lain untuk yang kedua kalinya yang dapat mewujudkan kebahagiaan untuknya dengan lahirnya anak-anak. Serta terpenuhinya insting rasa cintanya terhadap anak-anak. ${ }^{49}$

\section{Mashlahah Poligami dalam Kompilasi Hukum Islam}

Menurut KHI dan Undang-Undang Nomor 1 Tahun 1974, poligami adalah perkawinan yang mengacu pada beberapa

49 Rudi Nuruddin Ambary, "Perkawinan Poligami Yang Berkeadilan," Al-'Adalah, Volume I I, Nomor I (2017), 73-86. 
persyaratan dan alasan. Persyaratannya adalah bahwa suami mendapatkan persetujuan dari istrinya dan dibenarkan melalui persidangan di pengadilan. Dalam kaitannya dengan kebolehan poligami sebagaimana ditegaskan oleh Undang-Undang Nomor 1 Tahun 1974, secara otomatis implikasi dari poligami yang dilakukan oleh suami adalah pengaturan prinsip keadilan dalam menjalankan manajemen rumah tangganya. Menurut UndangUndang Nomor 1 tahun 1974 untuk menegakkan keadilan, suami yang bermaksud melakukan poligami harus dapat menjamin bahwa keadilan tersebut akan dilakukan dengan baik dan benar. ${ }^{50}$

Dalam pasal 5 ditegaskan hal-hal sebagai berikut:

Bahwa untuk dapat mengajukan permohonan kepada pengadilan, sebagaimana dimaksud dalam pasal 4 ayat (1) Undang-Undang ini, harus dipenuhi syarat-syarat sebagai berikut:

1. Adanya persetujuan dari istri/istri-istri;

2. Adanya kepastian bahwa suami mampu menjamin keperluan-keperluan hidup istri-istri dan anak-anak mereka;

3. Adanya jaminan bahwa suami akan berlaku adil terhadap istri-istri dan anak-anak mereka.

Tiga persyaratan di atas memberikan pemahaman bahwa suami yang hendak melakukan poligami adalah suami yang mendapat tempat di hati istri-istrinya sehingga ia mendapat persetujuan untuk poligami. ${ }^{51}$ Persyaratan yang diberikan dan ditetapkan dalam KHI dan UU ini menunjukkan bahwa memelihara jiwa, harta, dan diri merupakan bagian terpenting dalam berpoligami. Mashlahah yang ingin dicapai dalam KHI ini selaras dengan kajian fikih yang menginginkan bahwa perkawinan

50Muhammad Tahir Azhary, "Hukum Perkawinan Islam Dan UU No. I Tahun 1974," Jurnal Hukum \& Pembangunan, Volume 17, Nomor I (2017): 49-56. Lihat juga dalam M. Irfan Irfan, "Ambiguitas Pasal 2 Uu No I Tahun 1974: Sebuah Bentuk Diskriminasi Hukum," Al-'Adalah, Volume 10, Nomor 3 (2017), 343-352.

${ }^{51}$ Beni Ahmad Saebani and Syamsul Falah, Hukum Perdata Islam di Indonesia, (Bandung: Pustaka Setia, 2011), 117-118. 
itu memunculkan kasih sayang antar pasangan dan kehidupan sosial lingkungannya

Jika seorang laki-laki berlaku adil kepada istrinya, dan dia sama ratakan semua anak-anaknya dalam pendidikan, pelajaran, dan nafkah serta dia letakkan batasan bagi setiap istri yang tidak boleh dilanggar, maka dia ikut andil besar dalam mencabut bibit fitnah dan keburukan, serta rasa iri dan benci sesama anggota keluarganya. Jika setelah itu, masih ada rasa cemburu yang dialami dalam diri istri dan anak-anak, maka itu adalah sesuatu yang biasa, yang tidak bisa dilepaskan maka semua itu dapat diatasi dengan sikap kebijaksanaan dan keadilannya seorang suami. Pendekatan mashlahah juga dimunculkan oleh KHI untuk membatasi mereka yang ingin poligami dengan mengatasnamakan syariat Islam, padahal sangat jelas dalil yang menjadi acuan prasyarat berpoligami.

Ada ada beberapa pasal yang menjelaskan persyaratan yang harus dilakukan oleh suami ketika ingin berpoligami dan sama dalam kitab Figh al-Islam wa Adillatuhu, tetapi ada beberapa tambahan lagi persyaratan yang ditambah di dalam KHI tersebut diantaranya, pasal 56, pasal 57, dan pasal 58.

Persyaratan poligami yang harus dipenuhi seorang suami menurut penulis sendiri ialah adanya rasa keadilan dalam hal ini adil dalam memberikan nafkah serta perhatian kepada anak dan istrinya, serta syarat yang lebih krusial lainnya ialah persetujuan atau izin langsung dari sang istri. Hal ini menurut penulis sangat perlu dijadikan suatu syarat utama dari berpoligami, mengingat pada zaman sekarang banyak para suami yang kawin lagi tanpa sepengetahuan sang istri. Kemudian menimbulkan sengketa waris apabila si suami meninggal di kemudian hari dikarenakan ketidaktahuan para pihak. Maka perlulah adanya izin dari sang istri tersebut dan disahkannya di pengadilan agar status poligami yang dilakukan suami itu mempunyai kekuatan hukum.

Tujuan utama dalam KHI lebih mengarah pada penyesuaian dengan legalitas bangsa yang bermartabat dan menghargai pihak 
perempuan dalam menjalin hubungan rumah tangga agar mendapat kebaikan dan kemaslahatan dari faktor harta, jiwa, sosial masyarakat, bahkan pemerintah. Sebaliknya jika tidak mampu mencapai itu semua, maka dikhawatirkan akan menimbulkan mudharat, maka dianjurkan hanya memiliki satu orang istri demi kemaslahatan dan menghidari dari rusaknya bahtera rumah tangga.

\section{Penutup}

Legalitas hukum agama di Indonesia menganut fikih Islam yang memiliki karakter konsep mashlahah dalam implementasi sosialnya. Pembatasan dan pemberian prasyarat berpoligami dalam Kompilasi Hukum Islam selaras dengan Fikih Islam yang mengizinkan para suami untuk menikah lebih dari satu orang istri dengan ketentuan utama adalah memberikan manfaat dan menghindarkan kemudharatan. Kompilasi Hukum Islam dan Fikih Islam merupakan satu kesatuan yang saling melengkapi dalam masalah poligami dan demi memperbaiki tatanan hidup masyarakat yang beragama di Indonesia. Pendekatan Mashlahah berpoligami dalam KHI lebih mengarah pada penyesuaian kemampuan jiwa, pemberian nafkah yang layak, tidak ada tendensi antar keluarga mempelai, dan tidak menjadikan mudharat dalam rumah tangga dan lingkungan sosial masyarakat sekitarnya. Sementara teori mashlahah Wahbah Zuhaili dalam masalah poligami lebih mengarah pada pendekatan hakiki bukan sangkaan semata (zhanni) artinya praktik poligami harus benarbenar mencapai kebaikan dari syariat Islam secara jelas dan yakin bukan sekedar nafsu belaka. Prasyarat mashlahah Wahbah Zuhaili dan KHI memiliki kesamaan dalam masalah pemenuhan syarat berpoligami dan menghindari kemudharatan semaksimal mungkin.

\section{Daftar Pustaka}

Abdullah, Abdul Gani. Pengantar Kompilasi Hukum Islam dalam Tata Hukum Indonesia. Jakarta: Gema Insani, 1994. 
Adnan, Gunawan. Women and the Glorious Qur'ān: An Analytical Study of Women-Related Verses of Süra An-Nisa'. Universitätsverlag Göttingen, 2004.

Ambary, Rudi Nuruddin. "Perkawinan Poligami Yang Berkeadilan." Al-'Adalah, Volume 11, Nomor 1, 2017.

Anshari, Endang Saifuddin. Piagam Jakarta, 22 Juni 1945: Sebuah Konsensus Nasional Tentang Dasar Negara Republik Indonesia (1945-1959). Jakarta: Gema Insani, 1997.

Arifin, Zainal. "Jumlah Perempuan Yang Boleh Dipoligami Kajian Terhadap Al-Qur'an Surat Al-Nisa'ayat 3." Journal Analytica Islamica, Volume 1, Nomor 2, 2012.

Asril, A. "Eksistensi Kompilasi Hukum Islam Menurut UndangUndang Nomor 12 Tahun 2011 Tentang Pembentukan Peraturan Perundang-Undangan." Hukum Islam, Volume 15, Nomor 1, 2015.

Azhary, Muhammad Tahir. "Hukum Perkawinan Islam dan UU No. 1 Tahun 1974." Jurnal Hukum \& Pembangunan, Volume 17, Nomor 1, 2017.

B, M. Taufan. Sosiologi Hukum Islam: Kajian Empirik Komunitas Sempalan. Yogyakarta: Deepublish, 2016.

Baidhowi, Aris. "Hukum Poligami dalam Perspektif Ulama Fiqh." Muwazah, Volume 4, Nomor 1, 2013. http://ejournal.iainpekalongan.ac.id/index.php/Muwazah/article/ view/149.

Fanani, Mohammad Nurrizal. "Pemberian Izin Poligami Oleh Pengadilan Agama Kudus Ditinjau Dari Perspektif Hukum Islam." Universitas Muria Kudus, 2017. http://eprints.umk.ac.id/7263/.

Firdaus. "Telaah Kritis Hadis-Hadis Poligami". DisertasiUniversitas Islam Negeri Syarif Hidayatullah, Jakarta, 2008.

Hartama, Agil Fitra Muhshy Paradana, S. H. Darsono, Ni'ami Mutimatum, M. SH, and others. "Pertimbangan Hakim dalam Perkara Ijin Poligami (Studi Kasus Putusan Nomor 
1187/Pdt. G/2013/PA Bpp.)." Universitas Muhammadiyah Surakarta, 2016. http://eprints.ums.ac.id/42080/.

Harun, "Contemporary Issues and Development in the Global Halal Industry: Selected ...," Springer, accessed May 30, 2017 Hazim, Dee. Polygamy Preppers Guide: Five Fictional Stories about What Can Happen If You Are Caught Unprepared for a Polygamy Storm. Lust, Betrayal, Sex, Violence, Mayhem. Bloomington: Xlibris Corporation, 2014.

Irfan, M. Irfan. "Ambiguitas Pasal 2 Uu No 1 Tahun 1974: Sebuah Bentuk Diskriminasi Hukum." Al-'Adalah, Volume 10, Nomor 3, 2017.

Irianto, Sulistyowati. Perempuan dan Hukum: Мепијu Hukum Yang Berperspektif Kesetaraan dan Keadilan: 22 Tahun Konvensi Cedaw di Indonesia. Jakarta: Yayasan Obor Indonesia, 2006.

Krenawi (Al-), Alean. Psychosocial Impact of Polygamy in the Middle East. Berlin, Jerman: Springer Science \& Business Media, 2013.

Maragi (al-), Ahmad Mustafa. Tafsir al-Maragi Juz 4. Semarang: CV. Toha Putra Semarang, 1993.

Mulia, Musdah. Gender dalam Perspektif Islam. Jakarta: Kementerian Negara Pemberdayaan Perempuan, 2007.

Mushaf An-Nahdlah, Al-Qur'an dan Terjemah. Jakarta: PT. Hati Emas, 2014.

Nasution, Khoiruddin. Riba dan Poligami: Sebuah Studi Atas Pemikiran Muhammad Abduh. Yogyakarta: Pustaka Pelajar, 1996.

Nichols, Jeffrey D. Prostitution, Polygamy, and Power: Salt Lake City, 1847-1918. University of Illinois Press, 2002.

Nurlaelawati, Euis. Modernization, Tradition and Identity: The Kompilasi Hukum Islam and Legal Practice in the Indonesian Religious Courts. Amsterdam: Amsterdam University Press, 2010.

Putri, Widya Santika Wahyu, and others. "Kedudukan Hukum Hak Waris Orang Yang Memiliki Kelamin Ganda (Khuntsa 
Musykil) Ditinjau dari Instruksi Presiden Nomor 1 Tahun 1991 Tentang Kompilasi Hukum Islam dan Fatwa MUI." Fakultas hukum UNPAS, 2017. http://repository.unpas.ac.id/id/eprint/27463.

Qoshir (Al-), Fada Abdul Razak. Wanita Muslimah Antara Syari'at Islam dan Budaya Barat. Yogyakarta: Darussalam Offset, 2004. Quthb, Sayyid. Fi Zhilalil Quran. Beirut, Lebanon: Dar Syuruq, 1994.

------. Tafsir Fi Zhilalil Quran Di Bawah Naungan A-Quran, Vol. 2, 2 vols. Jakarta: Gema Insani, 2010.

Rahman, Abdul. Perkawinan dalam Syariat Islam. Jakarta: PT. Rineka Cipta, 1996.

Rohman, Holilur. "Batas Umur Pernikahan dalam Perspektif Hukum Islam: Studi Penerapan Teori Maslahah Mursalah." UIN Sunan Ampel Surabaya, 2009. http://digilib.uinsby.ac.id/id/eprint/7389.

Saebani, Beni Ahmad, and Syamsul Falah. Hukum Perdata Islam di Indonesia. Bandung: Pustaka Setia, 2011.

Saija, R. dan Iqbal Taufik. Dinamika Hukum Islam Indonesia. Yogyakarta: Deepublish, 2016.

Sanan, Arij Abdurrahman. Memahami Keadilan Dalam Poligami. Jakarta: Globalmedia Cipta Publishing, 2003.

Shalabi, Muhammad Musthafa. Al-Madkhal Fi Al-Figh Al Islamy. 10th ed. Beirut, Lebanon: Dar al Jami'ah, 1405.

Shalih, Abdul Aziz ibn Fauzan ibn. Fikih Sosial: Tuntunan dan Etika Hidup Bermasyarakat. Jakarta: Qisthi Press, 2016.

Sirin, Khaeron. Perkawinan Mazhab Indonesia: Pergulatan Antara Negara, Agama, dan Perempuan. Yogyakarta: Deepublish, 2016.

Sofyan. "Analisis Pemikiran Musdah Mulia Terhadap Keharaman Poligami." Bil Dalil, Volume 1, Nomor 02, 2017.

Sulayman, Abdul Hamid Abu. Towards an Islamic Theory of International Relations: New Directions for Islamic Methodology 
and Thought. International Institute of Islamic Thought (IIIT), 1987.

Sunaryo, Agus. "Poligami Di Indonesia (Sebuah Analisis Normatif-Sosiologis)." Yin Yang, Volume 5, Nomor 1, 2010.

Syukur, Abd Kadir. Hukum Perkawinan Di Indonesia. 1st ed. Barito Kuala KalSel: LPKU, 2015.

Undang-Undang Republik Indonesia Nomor 1 Tahun 1974 Tentang Perkawinan dan Kompilasi Hukum Islam. Cetakan I: Grahamedia Press, 2014.

Usman. "Perdebatan Masalah Poligami Dalam Islam (Kajian Tafsir Al-Maraghi QS. Al-Nisa'ayat 3 Dan 129)." Anida', Volume 39, Nomor 1, 2014.

Widodo, Aminudin Slamet. "Konsep Maslahah Mursalah Wahbah Zuhaili dan Relevansinya dengan Pernikahan Sirri di Indonesia." UIN Maulana Malik Ibrahim Malang, 2011.

Yango, Huzaimah T. dan Zaitunah Subhan (Ed). Membendung liberalisme. Jakarta: Penerbit Republika, 2006.

Zeitzen, Miriam Koktvedgaard. Polygamy: A Cross-Cultural Analysis. London: A\&C Black, 2008.

Zuhaili (Al-), Wahbah. Al-Figh Al-Islâm Wa Adillatuh. Vol. III. (Damaskus: Dar-Fikr, 1989.

------. Figh al-Islam wa Adillatuh. Vol. 9. Beirut: Dar al-Fikr, 2004.

-----. Fiqih Islam 9, 1 st ed. Jakarta: Gema Insani, n.d. 